\title{
ACTIVATED NATURAL ZEOLITES FOR PETROLEUM HYDROCARBONS ADSORPTION
}

\author{
MARIA-ALEXANDRA HOAGHIA ${ }^{a}$, IOAN ASCHILEAN ${ }^{b}$, \\ VANDA BABALAU-FUSS ${ }^{\mathrm{a}, \mathrm{c}}$, ANCA BECZE ${ }^{\mathrm{a}}$, OANA CADAR ${ }^{\mathrm{a}}$, \\ CECILIA ROMAN ${ }^{\mathrm{a}}$, MARIUS ROMAN ${ }^{\mathrm{a}}$, MARIN SENILA ${ }^{\mathrm{a}}$, \\ ENIKO KOVACS ${ }^{a, c^{*}}$
}

\begin{abstract}
This study was carried out with the aim of increasing and determining the activated zeolites' adsorption capacity by testing their efficiency on petroleum hydrocarbons. Natural zeolite samples were sequentially studied after thermal and chemical activations. The results indicated that after the activations, the zeolite samples gained an increasing adsorption capacity of petroleum hydrocarbons. Furthermore, the zeolites with small particulate sizes $(<10 \mu \mathrm{m})$ have a higher adsorption capacity than the zeolites with a granulometry of $1-3 \mathrm{~mm}$. The metal content ranged between $4200-7400$ mg/kg Na, $15090-22990$ mg/kg Ca, 2670-3950 mg/kg Mg, 19470$19670 \mathrm{mg} / \mathrm{kg} \mathrm{K}, 6140-7210 \mathrm{mg} / \mathrm{kg}$ Fe and $149-178 \mathrm{mg} / \mathrm{kg} \mathrm{Mn}$. Mineralogical analyzes (X-ray diffraction - XRD and scanning electron microscopy - SEM) were applied for the characterization of the zeolites. According to the XRD results, the zeolites are characterized by a $64 \%$ crystallization level. The main mineral which was determined was Clinoptilolite-Ca. The SEM micrographs indicate the morphology of zeolite surfaces.
\end{abstract}

Keywords: zeolites, thermal treatment, chemical activation, adsorption capacity

\section{INTRODUCTION}

Petroleum hydrocarbons are a valuable fuel source, as well as a raw material for a wide range of industrial applications all over the world. On the

\footnotetext{
a INCDO-INOE 2000, Research Institute for Analytical Instrumentation subsidiary, ICIA ClujNapoca, 67 Donath, RO-400293, Cluj-Napoca, Romania

b Zeolites Production S.A., 359 Republicii, RO-505500, Rupea, Romania

c University of Agricultural Science and Veterinary Medicine, 3-5 Calea Manastur, RO-400372, Cluj-Napoca, Romania,

*Corresponding author: eniko.kovacs@icia.ro
} 
other hand, they are a major environmental polluter, being classified as priority pollutants [1]. Oil and oil products spillages generate considerable damages, thus, more focus is being given to the development of advanced solutions to eliminate these pollutants. Besides the environmental impact of petroleum hydrocarbons, these pollutants cause a major risk to both humans and other forms of life [2, 3, 4, 5]. Ahmed and Fakhruddin [6] provided an overview on the impact of petroleum hydrocarbons on soil, water, and human health, as well as on the use of microorganisms for their degradation.

Different techniques and solutions are being used for the isolation, treatment, removal and control of petroleum-polluted environments. The decontamination technique using zeolites as adsorbents proved to be beneficial to the economy and to the environment $[7,8]$.

Zeolites are crystalline aluminosilicates composed of three-dimensional structures of $\mathrm{AlO}_{4}$ and $\mathrm{SiO}_{4}$ tetrahedra bound together by oxygen ions. Molecular sieves are a term that is often used to describe them. They are expressed chemically by the analytical formula: $\mathrm{M}_{2} / \mathrm{nOAl}_{2} \mathrm{O}_{3} \cdot \mathrm{ySiO} \cdot \mathrm{wH}_{2} \mathrm{O}$, where $y$ is 2-200; $n$ is the cation valence and $w$ is the water contained in the voids [9].

Due to their structure, both synthetic and natural zeolites have been used in many industrial processes such as adsorption (gas separation), catalysis (petroleum refining, petrochemical production), separation (detergents, soaps). Many studies focus on synthetic zeolites used as mineral sorbents of diesel fuels and used engine oil [10], as sorbents of benzene, toluene, pxylene (BTX) [11], as desulfurization sorbents of hydrocarbon fuels, containing benzothiophene and dibenzothiophene [12].

Among the natural zeolites, clinoptilolite has been widely used due to its abundance and ion exchange properties. In a study conducted by Favvas et al [13], clinoptilolite from the area of Drista River (North Greece) was used as a dehydration agent of diesel fuels and their findings indicated an increase in the physicochemical properties of the analyzed fuels. Natural clinoptilolite's potential as a Fenton catalyst in the removal of aromatic hydrocarbons was investigated by Rusoo et al [14]. Al-Jamal et al [15] studied the potential of Jordanian raw zeolitic tuff in adsorbing the oil from oil-contaminated water, by the use of de-alumination and micro-emulsification treatments. Zeolites originated from Romania have been used by different studies in environmental protection and medicine, such as biomonitoring of air pollution, waste water treatment, removal of $\mathrm{Fe}$ and $\mathrm{Mn}$ from diverse solutions, behavior of zeolites in simulated gastric fluid [16, 17, 18, 19].

In the present study, the determination of the adsorption capacity of a natural zeolite (clinoptilolite) was studied by using two activation methods: (i) thermal activation, and (ii) chemical activation, in order to increase the petroleum hydrocarbons adsorption capacity. 
The zeolites were activated with surfactants with the aim of increasing the petroleum hydrocarbons adsorption capacity. After the activation with surfactants, the surface of material is changed from hydrophilic to hydrophobic.

The findings will contribute to the understanding of the potential use of natural zeolites in improving petroleum hydrocarbons spill cleanup.

\section{RESULTS AND DISCUSSION}

\section{Zeolite characterization}

The physico-chemical and mineralogical characteristics of the zeolites (not activated, thermally activated, and thermally and chemically activated) under this study are indicated as it follows.

\section{$X$-ray diffraction (XRD) analysis}

The XRD patterns of the thermally activated (at $500^{\circ} \mathrm{C}$ ) zeolites are presented in figure 1.

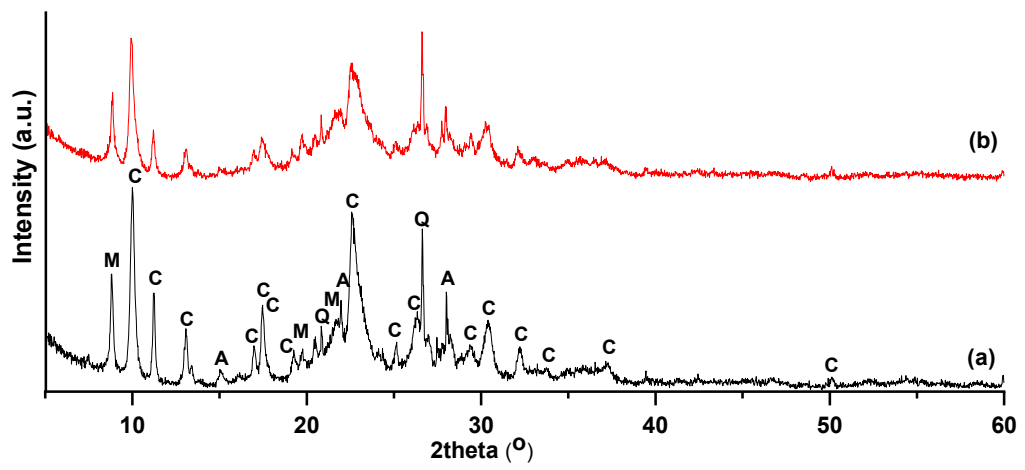

Figure 1. XRD patterns of thermally activated zeolites with particle sizes of (a) $<10 \mu \mathrm{m}$ and (b) 1-3 mm. Note: A- albite, C- clinoptilolite, Q- quartz, M- muscovite

According to the XRD analysis, the investigated zeolites contain clinoptilolite (00-070-1859) as the major crystalline phase, accompanied by muscovite (00-006-0263), quartz (00-005-0490) and albite (00-020-0548). The non-crystalline components were not quantified by the XRD analysis, but the presence of amorphous volcanic glass in zeolites is indicated by the broad diffraction hump at $2 \theta=20-25^{\circ}$. A slight decrease in the degree of crystallinity was remarked for higher particle size $(54.6 \%)$ comparing with lower particle size (63.6\%). 
MARIA-ALEXANDRA HOAGHIA, IOAN ASCHILEAN, VANDA BABALAU-FUSS, ANCA BECZE,

OANA CADAR, CECILIA ROMAN, MARIUS ROMAN, MARIN SENILA, ENIKO KOVACS

\section{Scanning electron microscopy (SEM) results}

SEM was applied for Az1 and Az2 zeolites, with particles dimensions $<10 \mu \mathrm{m}$ and $1-3 \mathrm{~mm}$, not activated and thermally activated at $500^{\circ} \mathrm{C}$.
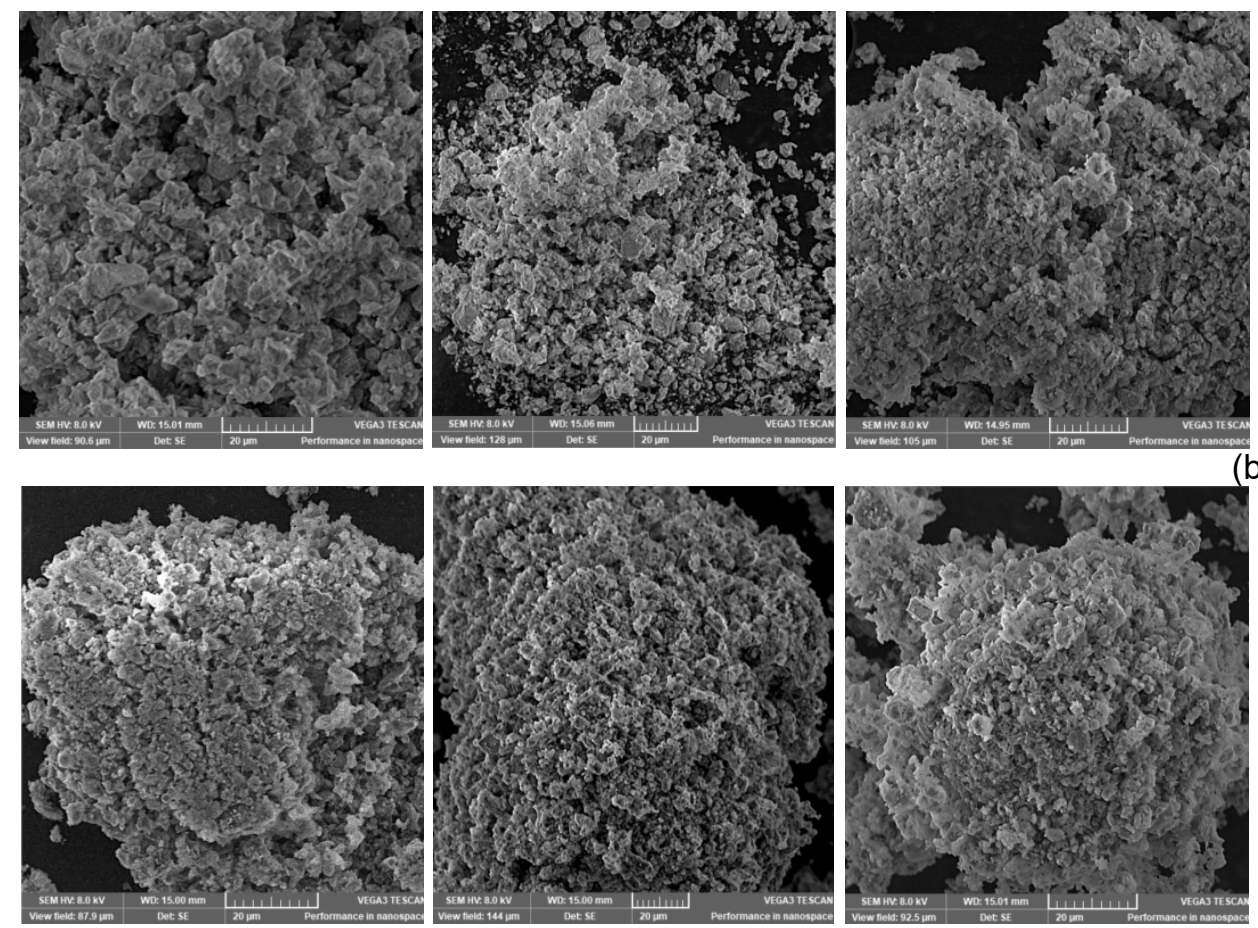

(a)

Figure 2. SEM micrographs indicating the occurrence of zeolites thermally activated a) Az1 (particle sizes < $10 \mu \mathrm{m}$ ) and $b$ ) Az2 (particle sizes 1-3 mm)

The Energy-Dispersive X-ray Spectroscopy (EDX) analysis indicate that the zeolites samples are characterized by concentrations of $43.0-61.7 \%$ silicon and $7.10-37.4 \%$ oxygen.

\section{Metals and oxides content}

The metals ( $\mathrm{Al}, \mathrm{Ca}, \mathrm{Fe}, \mathrm{K}, \mathrm{Mg}, \mathrm{Mn}, \mathrm{Na})$ and major oxides $\left(\mathrm{Al}_{2} \mathrm{O}_{3}, \mathrm{CaO}\right.$, $\mathrm{Fe}_{2} \mathrm{O}_{3}, \mathrm{~K} 2 \mathrm{O}, \mathrm{MgO}, \mathrm{MnO}, \mathrm{Na}_{2} \mathrm{O}$ ) contents in the zeolites only thermally activated were determined in a previous study [20]. The results indicate variations of the Al content between $59000-68000 \mathrm{mg} / \mathrm{kg}, \mathrm{Na}, \mathrm{Ca}, \mathrm{Mg}$ and $\mathrm{K}$ ranging between $4200-7400 \mathrm{mg} / \mathrm{kg}, 15090-22990 \mathrm{mg} / \mathrm{kg}, 2670-3950 \mathrm{mg} / \mathrm{kg}$ and $19470-19670 \mathrm{mg} / \mathrm{kg}$ [20]. Fe and Mn vary between $6140-7210 \mathrm{mg} / \mathrm{kg}$ and $149-178 \mathrm{mg} / \mathrm{kg}$. Generally, the metal content is higher in the zeolite with lower particle sizes [20]. 
In the current study, the results of the metals content in chemically activated zeolites are showed in Table 1.

Table 1. The metal content $(\mathrm{mg} / \mathrm{kg})$ in the chemically activated zeolites (Az3-Az8)

\begin{tabular}{|r|l|l|l|l|l|l|l|}
\hline Sample & Al & Ca & Fe & K & Mg & Mn & Na \\
\hline Az3 10 & 62524 & 15468 & 5210 & 18418 & 3470 & 147 & 4919 \\
\hline Az4 1-3 & 67886 & 20983 & 4204 & 17736 & 4207 & 229 & 3677 \\
\hline Az5 10 & 64747 & 16507 & 5698 & 19166 & 3521 & 157 & 4904 \\
\hline Az6 1-3 & 68875 & 20873 & 4607 & 17636 & 6298 & 157 & 3552 \\
\hline Az7 10 & 60386 & 15404 & 5391 & 18802 & 3408 & 144 & 4745 \\
\hline Az8 1-3 & 69882 & 20362 & 4594 & 18413 & 4669 & 133 & 3397 \\
\hline Mean & $\mathbf{6 5 7 1 7}$ & $\mathbf{1 8 2 6 6}$ & $\mathbf{4 9 5 1}$ & $\mathbf{1 8 3 6 2}$ & $\mathbf{4 2 6 2}$ & $\mathbf{1 6 1}$ & $\mathbf{4 1 9 9}$ \\
\hline Min & $\mathbf{6 0 3 8 6}$ & $\mathbf{1 5 4 0 4}$ & $\mathbf{4 2 0 4}$ & $\mathbf{1 7 6 3 6}$ & $\mathbf{3 4 0 8}$ & $\mathbf{1 3 3}$ & $\mathbf{3 3 9 7}$ \\
\hline Max & $\mathbf{6 9 8 8 2}$ & $\mathbf{2 0 9 8 3}$ & $\mathbf{5 6 9 8}$ & $\mathbf{1 9 1 6 6}$ & $\mathbf{6 2 9 8}$ & $\mathbf{2 2 9}$ & $\mathbf{4 9 1 9}$ \\
\hline
\end{tabular}

The Al concentrations vary between 60386 to $69882 \mathrm{mg} / \mathrm{kg}$, with higher values obtained in the zeolites with the particle sizes of 1-3 $\mathrm{mm}$ and particularly in Az8. The $\mathrm{Ca}, \mathrm{Mg}$ and $\mathrm{Mn}$ amounts are slightly higher in the not activated samples with particle size of 1-3 mm with values between 15404$20983 \mathrm{mg} / \mathrm{kg}, 3408-6298 \mathrm{mg} / \mathrm{kg}$ and $133-229 \mathrm{mg} / \mathrm{kg}$. For the $\mathrm{Fe}, \mathrm{K}$ and $\mathrm{Na}$, the highest values were found in the samples that were not activated with particle size $<10 \mu \mathrm{m}$. The amounts vary between 4204-5698 $\mathrm{mg} / \mathrm{kg} \mathrm{Fe}$, $17636-19166 \mathrm{mg} / \mathrm{kg} \mathrm{K}$ and 3397-4919 $\mathrm{mg} / \mathrm{kg} \mathrm{Na}$.

No significant variations are observed between the samples activated with different surfactant concentrations.

The major oxides results obtained for the chemically zeolites are indicated in Table 2.

Table 2. The major oxides content (\%) obtained in the chemically activated zeolites (Az3-Az8)

\begin{tabular}{|c|c|c|c|c|c|c|c|c|}
\hline Sample & $\mathbf{A l}_{2} \mathbf{O}_{3}$ & $\mathbf{S i O}_{\mathbf{2}}$ & $\mathbf{C a O}$ & $\mathbf{F e}_{2} \mathbf{O}_{3}$ & $\mathbf{K}_{\mathbf{2}} \mathbf{O}$ & $\mathbf{M g O}$ & $\mathbf{M n O}$ & $\mathbf{N a}_{\mathbf{2}} \mathbf{O}$ \\
\hline $\mathrm{Az3}$ & 11.8 & 67.3 & 2.17 & 0.74 & 2.22 & 0.58 & 0.02 & 0.66 \\
\hline $\mathrm{Az} 4$ & 12.8 & 68.1 & 2.94 & 0.60 & 2.14 & 0.70 & 0.03 & 0.50 \\
\hline $\mathrm{Az} 5$ & 12.2 & 67.0 & 2.31 & 0.81 & 2.31 & 0.59 & 0.02 & 0.66 \\
\hline $\mathrm{A} z 6$ & 13.0 & 66.4 & 2.92 & 0.66 & 2.13 & 1.05 & 0.02 & 0.48 \\
\hline $\mathrm{A} z 7$ & 11.4 & 65.7 & 2.16 & 0.77 & 2.27 & 0.57 & 0.02 & 0.64 \\
\hline $\mathrm{A} z 8$ & 13.2 & 68.2 & 2.85 & 0.66 & 2.22 & 0.78 & 0.02 & 0.46 \\
\hline Mean & $\mathbf{1 2 . 4}$ & $\mathbf{6 7 . 1}$ & $\mathbf{2 . 5 6}$ & $\mathbf{0 . 7 1}$ & $\mathbf{2 . 2 1}$ & $\mathbf{0 . 7 1}$ & $\mathbf{0 . 0 2}$ & $\mathbf{0 . 5 7}$ \\
\hline Min & $\mathbf{1 1 . 4}$ & $\mathbf{6 5 . 0}$ & $\mathbf{2 . 1 6}$ & $\mathbf{0 . 6 0}$ & $\mathbf{2 . 1 3}$ & $\mathbf{0 . 5 7}$ & $\mathbf{0 . 0 2}$ & $\mathbf{0 . 4 6}$ \\
\hline Max & $\mathbf{1 3 . 2}$ & $\mathbf{6 8 . 2}$ & $\mathbf{2 . 9 4}$ & $\mathbf{0 . 8 1}$ & $\mathbf{2 . 3 1}$ & $\mathbf{1 . 0 5}$ & $\mathbf{0 . 0 3}$ & $\mathbf{0 . 6 6}$ \\
\hline
\end{tabular}

The $\mathrm{Al}_{2} \mathrm{O}_{3}$ content varies between 11.4-13.2 \%, $\mathrm{SiO}_{2}$ 65.0-68.2 \%, while $\mathrm{Na}_{2} \mathrm{O}, \mathrm{CaO}, \mathrm{MgO}$ and $\mathrm{K}_{2} \mathrm{O}$ range between 0.46-0.66 \%, 2.16-2.94 \%, $0.57-1.05 \%$ and 2.13-2.31. The content of $\mathrm{Fe}_{2} \mathrm{O}_{3}$ varies between 0.60$0.81 \%$, whereas no significant differences are noticed in the MnO results. 
MARIA-ALEXANDRA HOAGHIA, IOAN ASCHILEAN, VANDA BABALAU-FUSS, ANCA BECZE, OANA CADAR, CECILIA ROMAN, MARIUS ROMAN, MARIN SENILA, ENIKO KOVACS study [20].

Metals in the thermally activated zeolites were indicated in a previous

\section{Petroleum hydrocarbon adsorption}

In order to increase the petroleum hydrocarbon adsorption, the surface of the zeolites is modified with surfactants. This activation changes the character or the surface from hydrophilic to hydrophobic, increasing the organic pollution affinity of the zeolite which acts like a sorbent [21, 22]. The activated zeolite samples chemically activated with surfactant (methyl dodecylbenzene sulfonate) solutions were tested to study the petroleum hydrocarbon adsorption capacity. The highest petroleum hydrocarbon adsorption capacity is observed at samples activated with the most concentrated surfactant solution (2.0 $\mathrm{mmol} / \mathrm{L}$ ). Results vary between 101-253 $\mathrm{mg} / \mathrm{g}$ adsorbed hydrocarbons by zeolites (Figure 3).

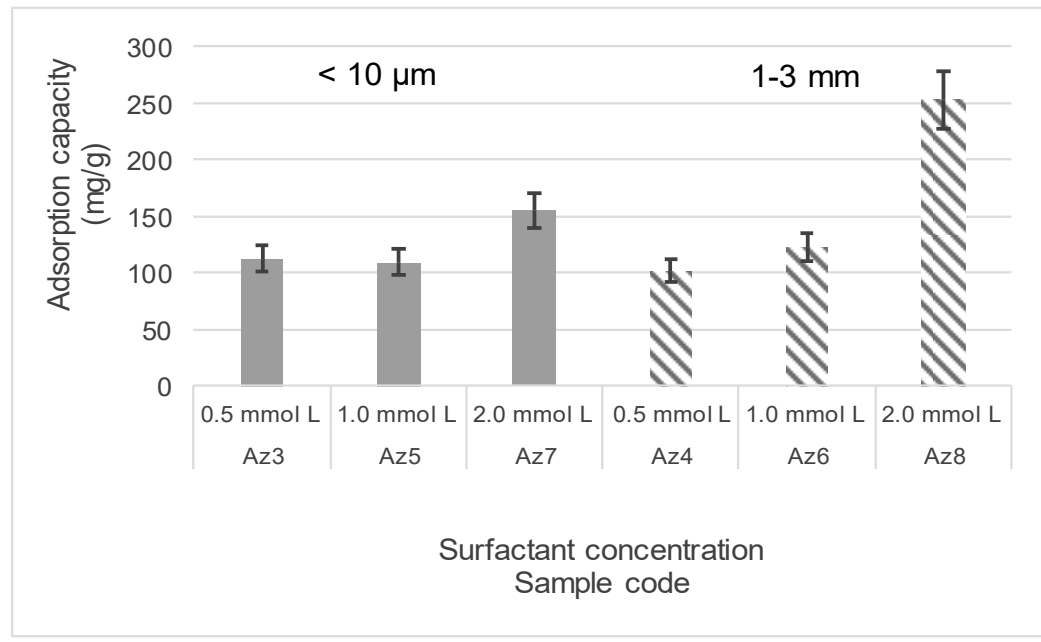

Figure 3. Adsorption capacity $(\mathrm{mg} / \mathrm{g})$ in the activated zeolites samples with two granulometries ( $<10 \mu \mathrm{m}$ and $1-3 \mathrm{~mm}$ ) with three different surfactant concentration levels $(0.5 \mathrm{mmol} / \mathrm{L}, 1.0 \mathrm{mmol} / \mathrm{L}, 2.0 \mathrm{mmol} / \mathrm{L})$

Samples with the highest granulometry and activated with the 2.0 $\mathrm{mmol} / \mathrm{L}$ surfactant solution are characterized by the highest petroleum hydrocarbon adsorption capacity. The increasing trend of the zeolite samples is the following $A z 6<A z 4<A z 3<A z 7<A z 5<A z 8$.

According to the results, an increase of the adsorption capacity was noticed. The zeolite treated with a high concentration of surfactant solution was the most effective $(2.0 \mathrm{mmol} / \mathrm{L})$. 
The results obtained by Torabian et al [23] also revealed that the zeolite's adsorption capacity is enhanced by the increase of surfactant loading.

Simpson et al. [24] examined the sorption of volatile petroleum hydrocarbons using surfactant modified zeolite and their results showed an increase in the sorption coefficient. The zeolites' affinity for hydrocarbons can be enhanced by transforming their surface from hydrophilic to hydrophobic, under the surfactants' action [25].

\section{CONCLUSIONS}

Based on the X-ray diffraction and scanning electron microscopy results, thermally activated zeolites contain clinoptilolite, quartz, muscovite and albite. The SEM micrographs indicate the occurrence of thermally activated zeolites and silicon and oxygen concentrations.

The $\mathrm{Al}, \mathrm{Ca}, \mathrm{Mg}$ and $\mathrm{Mn}$ concentrations were slightly higher in the zeolite samples with granulometry of 1-3 mm compared to the samples with lower granulometry $(<10 \mu \mathrm{m})$, while the $\mathrm{Fe}, \mathrm{Na}$ and $\mathrm{K}$ amounts were higher in the samples with lower particle sizes. According to the study's results, activated zeolites with $2.0 \mathrm{mmol} / \mathrm{L}$ methyl dodecylbenzene sulfonate solution were characterized by the highest petroleum hydrocarbon adsorption capacity. Likewise, the granulometry of samples play an important role in the increasing adsorption capacity.

\section{EXPERIMENTAL SECTION}

\section{Sampling, mechanical and thermal treatments}

The studied zeolite materials (clinoptilolite tuffs) were provided from the Rupea deposits (Brasov County, central Romania). Clinoptilolite-type minerals represent the predominant zeolite resources in these deposits and generally in the country $[26,27]$. After the collection, the samples were crushed and grounded and powdered at two different particle sizes $(<10 \mu \mathrm{m}$

and $1-3 \mathrm{~mm}$ ). Afterwards, the zeolites were dried at a temperature of $105^{\circ} \mathrm{C}$, using a thermostatic oven INE 200 (Memmert, Germany) for at least $5 \mathrm{~h}$. Then, they were thermally activated at $500{ }^{\circ} \mathrm{C}$ for a period of at least $2 \mathrm{~h}$, using an electrical oven model LT9 muffle furnace (Nabertherm, Lilienthal, Germany). Samples were left for cooling in a desiccator, transfused and kept in clean polyethylene bags until the chemical activation.

\section{Chemical activation}

The chemical activation consists of treating the zeolites with surfactant (methyl dodecylbenzene sulfonate) solutions. Three different surfactant solutions $(0.5 \mathrm{mmol} / \mathrm{L}, 1.0 \mathrm{mmol} / \mathrm{L}$ and $2.0 \mathrm{mmol} / \mathrm{L})$ were prepared. The samples were 
immersed (1:10, v:v) and homogenized for $24 \mathrm{~h}$ using a magnetic stirrer. Before the separation of the resulted phases, they were left to settle for 45 minutes. The solid phase was washed a coupled of times with distilled water in order to remove the surfactant. The activated zeolites were then dried at $45^{\circ} \mathrm{C}$ for $24 \mathrm{~h}$.

After the activation procedures, eight types of materials were obtained as indicated in Table 3.

Table 3. Characteristics for the obtained zeolite materials after three different activations

\begin{tabular}{|c|c|c|c|}
\hline Sample & Particle sizes & $\begin{array}{c}\text { Temperature } \\
\left({ }^{\circ} \mathbf{C} \text { ) }\right.\end{array}$ & $\begin{array}{c}\text { Concentration of methyl } \\
\text { dodecylbenzene sulfonate solution } \\
\text { (mmol/L) }\end{array}$ \\
\hline$A z 1$ & $<10 \mu \mathrm{m}$ & 500 & - \\
\hline$A z 2$ & $1-3 \mathrm{~mm}$ & 500 & - \\
\hline$A z 3$ & $<10 \mu \mathrm{m}$ & 500 & 0.5 \\
\hline$A z 4$ & $1-3 \mathrm{~mm}$ & 500 & 0.5 \\
\hline $\mathrm{Az5}$ & $<10 \mu \mathrm{m}$ & 500 & 1.0 \\
\hline $\mathrm{Az6} 6$ & $1-3 \mathrm{~mm}$ & 500 & 1.0 \\
\hline $\mathrm{Az7}$ & $<10 \mu \mathrm{m}$ & 500 & 2.0 \\
\hline $\mathrm{Az8}$ & $1-3 \mathrm{~mm}$ & 500 & 2.0 \\
\hline
\end{tabular}

\section{Characterization techniques}

\section{Scanning electron microscopy (SEM)}

The SEM was applied with a scanning electron microscope at $8 \mathrm{kV}$, using a TescanVEGA 3 SBU - EasyProbe model (NanoSystems MC, Czech). The field dimension was $146 \mu \mathrm{m}$ and the focalization distance at $20 \mu \mathrm{m}$.

\section{$X$-ray diffraction determination}

The X-ray diffraction patterns were recorded at room temperature using a D8 Advance (Bruker, Germany) diffractometer operating at $40 \mathrm{kV}$ and $40 \mathrm{~mA}$ with CuK $\alpha$ radiation $(\lambda=1.54060 \AA)$.

\section{Metals and major oxides determinations}

The metal content ( $\mathrm{Al}, \mathrm{Ca}, \mathrm{Fe}, \mathrm{K}, \mathrm{Mg}, \mathrm{Mn}, \mathrm{Na}$ ) was determined in the activated zeolites (Az3-Az8) after digesting a quantity of $1.0 \pm 0.001 \mathrm{~g}$ with $28 \mathrm{ml}$ of aqua regia using a closed digestion system DK6 VELP (Velp Scientifica, Usmate Velate, Italy). The solutions were left for at least $12 \mathrm{~h}$ at room temperature before the extraction. The extraction took 240 minutes at $120^{\circ} \mathrm{C}$. After the procedure was ended, the samples were filtered through $0.45 \mu \mathrm{m}$ acetate cellulose filters and brought at a volume of $100 \mathrm{~mL}$ with ultrapure water (obtained with a Merck system, Millipore, Merck). The samples were measured using an inductively coupled plasma optical emission spectrometer (ICP-OES), model Optima 5300 DV (Perkin Elmer, Canada). 
The obtained concentrations were used for the calculation of the proposed major oxides using conversion factors [19].

The quality assurance was accomplished by measuring soda feldspar BCS-CRM, no. 375/1 (Bureau of Analysed Samples Ltd). For the $\mathrm{SiO}_{2}$ determination, gravimetric method was applied [19].

\section{Petroleum hydrocarbon adsorption}

In order to determine the efficiency of the adsorption capacity, a simulation was caried out on contaminated ex-sites with petroleum hydrocarbons (diesel). Commercial diesel was used in the experiments, that consists of a mixture of hydrocarbons having different carbon number in the range between $\mathrm{C} 10-\mathrm{C} 22$, which are mainly aliphatic and aromatic in nature [28]. Three chemical parameters were used to characterize the diesel: sulphur, sulfated ash content and the acid number.

Sulfur was determined by ICP-OES, as previously described, the sulfated ash content was determined gravimetrically and the acid number by titration with $\mathrm{HCl}$ against bromocresol green. The results indicated that the used diesel in the adsorption method was characterized by $3.0 \mathrm{mg} / \mathrm{kg} \mathrm{S}, 0.02 \%$ for the sulfated ash content and the acid number with values below $0.01 \mathrm{mgKOH} / \mathrm{g}$.

The adsorption capacity was gravimetrically determined. The zeolites were weighted and added as a uniform thin layer on the contaminated site. The samples were left for adsorption for $8 \mathrm{~h}$. Afterwards, the contaminated zeolites were carefully and quickly removed and weighed.

After the adsorption of petroleum hydrocarbons, the resulted zeolitespetroleum hydrocarbons mixtures could be used as fuel resources in cogeneration stations. Zeolites could be regenerated, but this implies a serious use of chemicals and/or energy in order to eliminate the amount of petroleum hydrocarbons and to purify the zeolite.

\section{ACKNOWLEDGMENTS}

This work was supported by the Competitiveness Operational Programme of the Ministry of European Funds through the Contract No. 7/ 01.09.2016, MY SMIS 105654.

\section{REFERENCES}

1. ${ }^{* * *}$ Agency for Toxic Substances and Disease Registry (ATSDR), 1999, Toxicological Profile for Total Petroleum Hydrocarbon, US Department of Health and Human Services, Public Health Service, Atlanta, Ga, USA. https://www.atsdr.cdc.gov/toxfaqs/tfacts123.pdf

2. S.J. Varjani; Bioresour. Technol., 2017, 223, 277-286.

3. P.W. Sammarco; S.R. Kolian; R.A.F. Warby; J.L. Bouldin; W.A. Subra; S.A. Porter; Arch. Toxicol., 2016, 90, 829-837. 
MARIA-ALEXANDRA HOAGHIA, IOAN ASCHILEAN, VANDA BABALAU-FUSS, ANCA BECZE, OANA CADAR, CECILIA ROMAN, MARIUS ROMAN, MARIN SENILA, ENIKO KOVACS

4. S. Adipah; JESPH, 2019, 3, 001-009.

5. I.C. Ossai; A. Ahmed; A. Hassan; F.S. Hamid; Environ. Technol. Innov., 2020, 17, 100526.

6. F. Ahmed; A.N.M. Fakhruddin; Int. J. Environ. Sci. Nat. Res., 2018, 11, 063-069.

7. T.N. Shchemelinina; L.A. Gomze; O.B. Kotova; J.E.F.M. Ibrahim; D.A. Shushkov; M. Harja; G.V. Ignatiev; E.M. Anchugova; JSBCM, 2019, 71, 131-137.

8. B. Saremnia; A. Esmaeili; M.R. Sohrabi; Can. J. Chem., 2016, 94,163-169.

9. E.M. Flanigen; R.W. Broach; S.T. Wilson; Introduction. In Zeolites in Industrial Separation and Catalysis, S. Kulprathipanja Ed.; Wiley-VCH Verlag Gmbh \& Co., Weinheim, Germany, 2010, Chapter 1, pp. 1-26.

10. L. Bandura; M. Franus; G. Jozefaciuk; W. Franus; Fuel, 2015, 147, 100-107.

11. B. Szala; T. Bajda; J. Matusik; K. Zieba; B. Kijak; Microporous Mesoporous Mater., 2015, 202, 115-123.

12. K.X. Lee; G. Tsilomelekis; J.A. Valla; Appl. Catal. B-Environ., 2018, 234, 130-142.

13. E.P. Favvas; C.G. Tsanaktsidis; A. Sapalidis; G.T. Tzilantonis; S.K. Papageorgiou; A.C. Mitropoulos; Microporous Mesoporous Mater., 2016, 225, 385-391.

14. A.V. Russo; L.F. Toriggia; S.E. Jacobo; J. Mater. Sci., 2014, 49, 614-620.

15. N. Al-Jamal; T. Juzsakova; B. Zsirka; V. Sebestyen; J. Nemeth; I. Cretescu; T. Halmagyi; E. Domokos; A. Redey; J. Environ. Manage., 2019, 239, 333-341.

16. L. Levei; A.I. Torok; O. Cadar; E.A Levei.; A. Ozunu; $20^{\text {th }}$ International Multidisciplinary Scientific GeoConference Proceedings SGEM, 2020, 313-320, DOI: $10.5593 /$ sgem2020/4.1/s19.039.

17. A. Moldovan; O. Cadar; E.A. Levei; F. Puskas; M. Senila; $20^{\text {th }}$ International Multidisciplinary Scientific GeoConference Proceedings SGEM, 2020, 281-288, DOI: $10.5593 /$ sgem2020/3.1/s12.037.

18. E. Neag; A.I. Torok; C. Tanaselia; I. Aschilean; M. Senila; 2020, 12, 1614, DOI: 10.3390/w12061614

19. O. Cadar; M. Senila; M.A. Hoaghia; D. Scurtu; I. Miu; E.A. Levei; Molecules, 2020, 25, 2570, DOI:10.3390/molecules25112570.

20. M.A. Hoaghia; E. Kovacs; C. Roman; M. Senila; I. Aschilean; $20^{\text {th }}$ International Multidisciplinary Scientific GeoConference - SGEM, 2020, 109-116, DOI: 10.5593/sgem2020/6.1/s24.015.

21. B. Muir; T. Bajda; Fuel Process. Technol., 2016, 149, 153-162, DOI: 10.1016/j.fuproc.2016.04.010.

22. L. Bandura; M. Franus, R. Panek; A. Woszuk; W. Franus; Przem. Chem., 2015, 94, 323-327, DOI 10.15199/62.2015.3.11.

23. A. Torabian; H. Kazemian; L. Seifi; G.N. Bidhendi; A.A. Azimi; S.K. Ghadiri; Clean, 2010, 38, 77-83, DOI: 10.1002/clean.200900157.

24. J.A. Simpson; R.S. Bowman; J. Contam. Hydrol. 2009, 108, 1-11.

25. L. Bandura; A. Woszuk; D. Kołodynska; W. Franus; Minerals, 2017, 7, 1-25.

26. M. Senila; O. Cadar; I. Miu; Molecules, 2020, 25, 2591, DOI: $10.339 /$ molecules25112591.

27. A. Maicaneanu; H. Bedelean; M. Stanca; Natural zeolites. Characterization and applications in environmental protection; Presa Universitara Clujeana, ClujNapoca, Romania, 2008, 324 p.

28. N. Patel; K.P. Shadangi; Mater.Today, 2020, 33, 4933-4936.

DOI: 10.1016/j.matpr.2020.02.679. 